\title{
Rating of Information Sources / Channels of Social Work Lecturers and Their Students: A Case Study of University Of Nigeria, Nsukka. \\ by
}

Abstract

Obidike N. A. (MRS). and Ekere F.C.

\begin{abstract}
The study was design to discern the information sources or channels of the academic staff and students of Social Work Department in University of Nigeria, Nsukka. Descriptive survey study based on questionnaire distribution and interview was adopted. The study was conducted during the second semester period of 2006/2007 academic session. Target participants were all the lecturers (10) and students (300) of the Department of Social Work (SWK), University of Nigeria, Nsukka. Analysis of data collected from the responses of the respondents using the modified Likert rating scale to identify the items with means 2.50 and above which indicated agreement. Useful statements made by the interviewees were also incorporated in the results to strengthen the findings of this study. The study revealed among others that lecturers and students of SWK Department in UNN believed that internet (3.50 and 3.04) is their major preferred information source for their academic work. The study also revealed that lecturers and students of SWK in UNN mainly use Internet for educational purposes (3.75). The interview report showed that Social Work lecturers and their students explore a number of information sources and that only three journals in the Social Work discipline exist in Nnamdi Azikiwe library, University of Nigeria, Nsukka.
\end{abstract}

\section{Introduction}

Social work is an arm of social science that is concerned with interaction between people and social environment that affects their ability to accomplish life tasks, alleviate distress and realize their aspiration and values (Pincus and Anne, 1973). It is a professional activity of helping individuals, group or communities to enhance or restore their capacity for social functioning and to create social conditions favourable to their goals. To function effectively, these group of social scientists need to harness their information using adequate information sources or channels. From the work of Nzotta (1987), cited by Folorunso (2004), information is the facts in form of written or unwritten intelligent communications and knowledge gathered from various sources. These sources of information are information channels or places where they (information) come from or are got. Hans - Christoph Hobohm (1999a) in the work he did for UNESCO World Social Science Report was worried about the social science (social work) information sources and channels. In recent times, the number of information resources has increased quite considerably. Obviously, information environments, sources/ channels, especially the internet, regardless of the enormous advantages, is riddled with new challenges and problems. Again, the retrieval of information from various sources/ channels by users' is becoming more complex. EMC Corporation's study in 2007 was of the opinion that the 2006 digital universe was 161 billion gigabytes (161 exabytes) in size. This finding also forecasted a six - fold annual information growth from 2006 to 2010. In the light of this assertion, the so called information explosion is real. It is against this background that this study was designed to discern the actual information sources/ channels of UNN social work lecturers and their students.

\section{Research questions}

The following research questions were raised

1) What are the information sources or channels of the Social Work lecturers and their students?

2) What are the relevant materials that Social Work lecturers and their students seek for at Nnamdi Azikiwe library, University of Nigeria, Nsukka?

3) How relevant is the use of the Internet as an information source, to lecturers and students of Social Work Department, University of Nigeria, Nsukka?

\section{Materials and Methods}

Study design - A descriptive survey design was used. This type of design was chosen for this work because of the population size (300 students and 10 lecturers) and the pattern of the questionnaire that consisted of many variables. Descriptive survey enables one to summarize a large body of data, consisting of one or more variables, to make them intelligible (Carpenter and Vasu, 1978). All 300 students and 10 lecturers in the Department of Social Work, 
University of Nigeria, Nsukka during the second semester of 2007 were sampled.

Questionnaire development - Two sets of questionnaire were developed. One set for the students $(100-400$ levels $)$ and the other set, for the lecturers. The closed ended questions that were raised required participants (students and lecturers of the Department of Social Work, UNN) to indicate their responses according to the modified Likert scale (i.e. strongly agreed [SA- 4 points], Agreed [A- 3 points], Disagreed [D - 2 points] and Strongly Disagreed [SD - 1 point]). A total of 6 questions with 44 items were raised for students of Social work (SWK), UNN. The questions consisted of personal information which included student demographics or biodata. Core questions that centered on the research interest were related to information sources and channels, materials mostly sought for at Nnamdi Azikiwe library, UNN, and use of internet facilities. In the same manner, a total of 5 questions with 62 items were raised for lecturers of SWK. The questions comprised of personal information (biodata) and core questions of interest that centered on information sources and channels, tracking of recent developments in the field of Social Work, sourcing of materials from Nnamdi Azikiwe library, UNN, and use of internet facilities. Interview schedule directed to two lecturers of the Social Work department helped in discussing the results of this study. The interview questions were structured in line with those of the questionnaire.

\section{Administration of Instruments}

\section{Results}

Table 1: Information sources of Social Work lecturers (mean and \pm SD)

\begin{tabular}{lccc}
\hline & N & Mean & $\mathbf{\pm}$ SD \\
\hline Discussion with fellow lecturers (colleagues) & 8 & 2.88 & .835 \\
Consultation with knowledgeable person in the field & 8 & 3.13 & .835 \\
Holding discussion with the librarian or reference staff of UNN library & 8 & 2.38 & .518 \\
Discussion with librarian outside UNN library & 8 & 2.25 & .463 \\
Review articles & 8 & 2.88 & .835 \\
Abstracting journals & 8 & 2.88 & .641 \\
Indexing journals & 8 & 2.88 & .641 \\
Library catalogue & 8 & 3.88 & .518 \\
Via internet & 8 & 3.50 & .756 \\
Through bibliographies compiled by UNN library & 8 & 2.38 & .744 \\
Book review & 8 & 2.63 & .744
\end{tabular}


Table 2: Channels used by SWK lecturers in tracking recent development in the field (mean and \pm SD)

\begin{tabular}{lccc}
\hline & $\mathbf{N}$ & Mean & $\mathbf{\pm S D}$ \\
\hline Core journals & 8 & 3.50 & .926 \\
Online search update & 8 & 3.63 & .744 \\
Newspapers & 8 & 2.13 & .354 \\
Conferences & 8 & 2.63 & .744 \\
Magazines & 8 & 2.25 & .463 \\
Book (social work text book) & 8 & 2.88 & .835 \\
Catalogues & 8 & 2.55 & .463 \\
\hline
\end{tabular}

Table 3: Information sources of Social Work students (mean and \pm SD)

\begin{tabular}{lccc}
\hline & N & Mean & 土SD \\
\hline Discussion with fellow students & 300 & 2.99 & 1.060 \\
Consultation with knowledge person in the field & 300 & 2.65 & 1.145 \\
Holding discussion with the librarian or reference staff of UNN library & 300 & 2.27 & .966 \\
Discussion with librarian or reference staff of other library outside UNN library & 300 & 1.88 & .760 \\
Review articles & 300 & 1.77 & .753 \\
Abstracting journals & 300 & 2.78 & .955 \\
Project supervisor & 300 & 2.46 & 1.009 \\
Indexing journals & 300 & 2.54 & .982 \\
Library catalogue & 300 & 1.89 & .891 \\
Through radio and television & 300 & 2.72 & 1.013 \\
Via internet & 300 & 3.04 & 1.004 \\
Bibliography compiled by UNN library & 300 & 2.61 & 1.000 \\
\hline
\end{tabular}

Table 4: Materials that Social Work lecturers seek for at Nnamdi Azikiwe library, UNN (mean and \pm SD)

\begin{tabular}{lccc}
\hline & N & Mean & $\mathbf{\pm S D}$ \\
\hline Social work textbook & 8 & 3.75 & .463 \\
Periodicals & 8 & 3.38 & .916 \\
Newspapers & 8 & 2.25 & .463 \\
Government publications & 8 & 2.88 & .835 \\
Reference book & 8 & 2.88 & .641 \\
Pamphlets & 8 & 2.00 & .000 \\
General books & 8 & 2.63 & .744 \\
Educational video cassettes & 8 & 2.13 & .641 \\
Educational CD plates & 8 & 3.00 & .926 \\
\hline
\end{tabular}

Table 2 above shows channel used by UNN Social Work lecturers in tracking recent development in the field. Social Work lecturers employ channels such as online update (3.63), core journals (3.50), Social Work text books (2.88) and conferences (2.63) in tracking recent development in the field of Social Work.

Shown in Table 3 above are information sources preferred by the UNN Social Work students. Students of Social Work in UNN make use of the internet (3.04) and discussion with fellow students (2.99) as their major information sources. Other means through which these categories of students source their information include: abstracting journals (2.78), radio and television (2.72), consultation with knowledgeable person in the field (2.65), bibliography compiled by UNN library (2.61) and indexing journals (2.54).

List of materials that UNN Social Work lecturers seek for at Nnamdi Azikiwe library are presented in Table 4. Social Work text books (3.75) stand out as the major material that the academic staff of Social Work Department seek for at Nnamdi Azikiwe library, UNN. Other identified materials which these lecturers seek for include: 
periodicals (3.38), educational CD plates (3.00), government publications, reference books with a mean of 2.88 respectively and general books (2.63). Educational CD plates may be very few at Nnamdi Azikiwe library, UNN but the

Table 5: Materials that Social Work students seek for at Nnamdi Azikiwe library, UNN (mean and \pm SD)

\begin{tabular}{lccc} 
& $\mathbf{N}$ & Mean & $\mathbf{\pm}$ SD \\
\hline Social work textbooks & 300 & 3.40 & .858 \\
General books. & 300 & 2.79 & .977 \\
Periodicals & 300 & 2.75 & .764 \\
Newspapers & 300 & 2.90 & 1.019 \\
Government publications & 300 & 2.20 & 1.132 \\
Reference books & 300 & 2.81 & .999 \\
Pamphlets & 300 & 2.41 & 1.042 \\
Master thesis reports & 300 & 1.55 & .573 \\
PhD thesis report & 300 & 1.48 & .563 \\
Undergraduate projects & 300 & 3.12 & .698 \\
Educational video cassettes & 300 & 2.21 & .998 \\
Educational CD plates & 300 & 2.32 & 1.040 \\
\hline
\end{tabular}

Table 6: Why lecturers of Social Work use Internet facilities (mean and \pm SD)

\begin{tabular}{lccc}
\hline & $\mathbf{N}$ & Mean & $\mathbf{\pm}$ SD \\
\hline For education & 8 & 3.75 & .707 \\
For entertainment & 8 & 1.88 & .354 \\
For news & 8 & 2.38 & .744 \\
For health information & 8 & 2.13 & .354 \\
For sports update & 8 & 2.00 & .000 \\
For social work information update & 8 & 3.50 & .926 \\
For e-mails & 8 & 2.88 & .835 \\
\hline
\end{tabular}

Table 7: Quality of information from the web as rated by Social Work lecturers (mean and \pm SD)

\begin{tabular}{lccc}
\hline & $\mathbf{N}$ & Mean & $\mathbf{\pm S D}$ \\
\hline Very good quality information & 8 & 2.88 & 1.246 \\
Good quality information & 8 & 2.38 & .744 \\
Fairly good quality information & 8 & 1.88 & .354 \\
Not of any good quality & 8 & 1.88 & .354 \\
\hline
\end{tabular}

Materials that Social Work students seek for at Nnamdi Azikiwe library, UNN are presented in Table 5. From the result of this study, Social Work students mainly look out for social work text books (3.40), undergraduate projects (2.81), Newspapers (2.90), reference books (2-81), general books (2.79), and periodicals (2.75) when they visit Nnamdi Azikiwe library in UNN. Other items had means lower than 2.50 and were not considered as major materials that these students seek for at Nnamdi Azikiwe library, UNN.

Various reasons why lecturers of Social Work department, UNN, use Internet facilities are presented in Table 6. Academic staff of Social
Work department at the University of Nigeria, Nsukka use Internet facilities mainly for educational purposes (3.75), social work information update (3.50), and electronic mail (2.88). Other usages had lower mean rating below 2.50 .

Presented in Table 7 above is the rating of the quality of information from the web by the lecturers of SWK department, UNN. Majority of the Social Work lecturers in UNN rated the quality of information from the web to be of "very good quality" (2.88). "Not of any good quality", "fairly good quality", and "good quality information" had lower mean ratings. 
Table 8: Rating of information sources of lecturers of Social Work (mean and \pm SD)

\begin{tabular}{lccc}
\hline & N & Mean & $\mathbf{\pm S D}$ \\
\hline Web & 8 & 3.50 & .926 \\
Radio & 8 & 2.13 & .354 \\
Television & 8 & 2.38 & .744 \\
Journals & 8 & 3.00 & .756 \\
Periodicals & 8 & 2.88 & .991 \\
Magazines & 8 & 2.25 & .463 \\
Fellow colleagues & 8 & 2.50 & .756 \\
\hline
\end{tabular}

Table 9: Reason why students of Social Work department use Internet facilities (mean and \pm SD)

\begin{tabular}{lccc}
\hline & $\mathbf{N}$ & Mean & $\mathbf{\pm S D}$ \\
\hline For educational purposes & 300 & 3.70 & .520 \\
For entertainment (chatting with friends) & 300 & 2.59 & .866 \\
For news & 300 & 2.75 & 1.023 \\
For health information & 300 & 2.73 & 1.024 \\
For sports update & 300 & 2.54 & 1.048 \\
For browsing & 300 & 3.18 & .912 \\
For e-mails & 300 & 3.15 & .958 \\
\hline
\end{tabular}

Table 10: Social Work students' rating of the quality of information from the web (mean and \pm SD)

\begin{tabular}{lccc}
\hline & $\mathbf{N}$ & Mean & $\mathbf{\pm S D}$ \\
\hline Very good quality information & 300 & 3.36 & .828 \\
Good quality information & 300 & 3.36 & .570 \\
Fairly good quality information & 300 & 2.08 & .814 \\
Not of any good quality & 300 & 1.70 & .770 \\
\hline
\end{tabular}

Table 11: Rating of information sources by students of Social Work (mean and \pm SD)

\begin{tabular}{lccc}
\hline & $\mathbf{N}$ & Mean & $\mathbf{\pm}$ SD \\
\hline Web & 300 & 3.50 & .598 \\
Radio & 300 & 3.07 & .983 \\
Television & 300 & 3.21 & .847 \\
Journals & 300 & 3.39 & .642 \\
Periodicals & 300 & 2.92 & .892 \\
Magazines & 300 & 2.88 & 1.016 \\
Other fellow students & 300 & 2.49 & 1.013 \\
Lecturers (supervisors) & 300 & 2.47 & 1.117 \\
Postgraduate students & 300 & 2.71 & 1.057 \\
\hline
\end{tabular}

Rating of information sources explored by lecturers of Social Work department, UNN is presented in Table 8. From Table 8 above, the study revealed that very good quality information (3.50) can be garnered from the web. Also good quality information can come from journals (3.00), periodicals (2.88) and fellow colleagues/lecturers (2.50).

Presented in Table 9 are the reasons why students of Social Work department in UNN use Internet facilities. The result of this study revealed that the students of Social Work department in UNN have wide diversity of reasons why they use Internet facilities. Great majority of these students use internet for browsing purposes (3.18) and electronic mail (3.15). Others use it for news (2.75), health information (2.75), educational purpose (2.70), entertainment (chatting with friends) (2.59) and sports update (2.54).

Social Work students' rating pertaining to the quality of information from the web is presented 
in Table 10. The bulk of the Social Work student respondents rated the quality of information from the web from being of good quality to very good quality (3.36).

Rating of various information sources by students of Social Work department in UNN is presented in Table 11. From Table 11 above, web (3.50), journals (3.39) television (3.21), radio (3.07), periodicals (2.92), magazines (2.88) and postgraduate students (2.71) were all identified as sources of very good quality information relevant to Social Work students' academic work.

\section{Interviews}

The result of the interview granted to two academic staff (The HOD and the predecessor) of SWK department, in UNN showed that lecturers and students of this department explore a number of information sources. Almost always, the information obtained is used for teaching and research work. The past head of the department pointed out that lecturers and students of SWK need information in areas of social work technique and social work behaviour. The interviewees also explained that they (lecturers and students of SWK) explore all legal means such as visiting the library, making use of internet services, consulting individuals/colleagues, going to other universities/institutions that have material in Social Work discipline to source for their much needed information. According to the HOD, the reason for wide area of sourcing information in Social Work stems from the fact that there is dearth of Social Work information materials at Nnamdi Azikiwe library, UNN. He pointed out that only three journals of Social Work are found in Nnamdi Azikiwe library, UNN. They include:

a. Journal of Social case work (vol. 56 (1), January, 1975. vol. 57 (1), January, 1976. vol. 60 (1), January, 1979. vol. 62 (1), January, 1981. vol. 64 (1), January, 1983).

b. Journal of Social work education (vol, 22 (1), January, 1986. vol.23 (1), February, 1987).

c. Journal of Social work (vol. 3 (1), April, 2003. vol. 3 (2), August, 2003. vol. 3 (3), December, 2003.

The comments garnered on the usefulness of the internet to Social Work discipline from the interviewees showed that the internet is second to none with regard to other sources of information. In the words of the past HOD, "the cyber (internet) is an improved technology in sourcing for information.

\section{Discussion}

The major preferred channels or sources of information for the academic staff of Social Work Department, in the University of Nigeria, Nsukka as revealed from this study include: Internet, discussion with fellow colleagues, consultation with knowledgeable persons in the field, review articles, journals and book review. For recent development in the field of Social Work, the lecturers of this department make use of journals, online search update, conferences and Social work textbooks. This assertion is buttressed by the work of Ellis et al., (1993), who clearly stated that Social scientists and physicists mainly track developments in their field through magazines, journals, books, catalogues, online search etc. According to Hans Christoph Hobohm, (1999b), Scholars are noted to build their information collections with a great variety of materials from conference papers to photocopied articles, research reports, books and reference materials. Unfortunately, the interview result of this study showed that there are not enough materials (textbooks and journals) on Social Work discipline in Nnamdi Azikiwe library, UNN. This library has only three journals in Social Work discipline (HOD, Social Work Dept, 2007). This observed remark is indeed not palatable considering the number of staff and students that will be scrambling for these three journals. There is no doubt that the non - availability of materials in Social Work discipline in Nnamdi Azikiwe library, UNN, will always limit the information source of lecturers and students of this department. Hobohm (1999) stated that Social scientists often use literature outside their own discipline (exception: Psychology and Economics). The data or information used by the Social sciences does not always come from Social science research, but mainly taken from context not indexed in Social sciences information system. Social scientists (Social workers inclusive) consider their institutional libraries only as last resort for more expensive or seldom used materials.

In line with their lecturers, students of Social Work Department, in UNN, also get information from a wide range of sources such as Internet, discussion with fellow students, consultation with knowledgeable persons in the field, journals, radio, and television and bibliography 
compiled by UNN library staff. Although, lecturers and students of Social Work Department in UNN explore various sources for acquisition of information, Wales (2000) revealed that journals appear to be the most popular source for current awareness purpose. This is not surprising because researchers in various disciplines publish their research findings and new innovations in journals.

The Internet eases access to a large amount of data, saves time and money, and obtains an opportunity to consult several experts with a single request (via discussion groups), and greater independence from specific time and place for easy information flow (Savolainen, 1999). From this study, the bulk of the Social Work lecturers make use of the Internet. These lecturers mainly go to access the web for educational purpose, for Social Work update and to send electronic mails. Some internet cafes in UNN campus include: UNN cyber café, Afrihub cyber café and UNN computing centre. Access to internet signal from UNN Management and information service (MIS) to all faculties and departments has not been efficient; perhaps due to poor management and inefficient internet radios mounted in the various faculties and departments. In the opinion of the SWK lecturers, the quality of information from the web is very good. The web is a laissez - faire information market place offering a huge diversity of sources, presenting information through a wide range of perspective (Dowine, 1996). Information often becomes available on the web more quickly than through print channels. On the other hand, use of the Internet brings exposure to unwanted materials. Most times during web browsing, one encounters unwanted materials (journals, books, advertisements placement etc). Use of the Internet does not guarantee any privacy. It is never advisable to write and send confidential matters via electronic mails. Internet is also prone to virus attack which almost always affects whatever information that is being stored in the flash drives or diskettes. This invariably may corrupt the files in the house or office computers when these information storage devices (diskette/flash) are inserted into these systems. Apart from the web, other identified good sources of information by Social Work lecturers include: journals, periodicals and fellow colleagues or lecturers. Students of SWK Department also use Internet facilities. From their questionnaire responses, they have wide diversity of reasons on why they visit the Internet centres on campus. A great majority of the SWK students use the Internet for browsing purposes and sending electronic mails. Others use it for news, educational purpose, entertainment, health information and sports update. It is commonplace in UNN to see students milling around Internet spots (UNN cyber café, Afrihub cyber café and UNN computing centre) on daily basis. SWK students in UNN also rated the quality of information from the web from being good to being of very good quality. Television, radio, journals, periodicals, magazines, and postgraduate students were identified by the students as other good sources of information.

In conclusion, this study has revealed that lecturers and students of Social Work department in UNN explore a wide variety of sources in acquiring information for their academic work. They mainly seek for Social Work textbooks in Nnamdi Azikiwe library. Lecturers and students of SWK were not left out as far as the use of Internet is concerned. Internet was identified in this study as their major preferred source of information. This being the case, there is great need for installation of Internet facilities in all the departments and faculties as well as in Nnamdi Azikiwe library, which is the heart beat of this University. This would enable lecturers and students (Social Work lecturers and their students) to access any library in Nigeria and outside Nigeria with Internet connectivity. With the provision of such facility, both in the library and in departments and faculties, lecturers and students will have easy access to download materials of their choice rather than go through the library shelves to source or look for books or other materials that may or may not contain the current information they are looking for.

\section{Recommendation}

For information resources to have a direct impact on the Social Work lecturers and their students in UNN, with regards to their identified information sources, the library (Nnamdi Azikiwe, library, UNN) needs to embark on two broad tasks, namely: liaising with the Department of Social Work to develop the appropriate collections and providing a number of new digital information services that can be accessed by not only lecturers and students of SWK but by many other users at a time. The new 
library complex in UNN should be able to accommodate and train new librarians, especially in Social Work to ensure that current journals, books and periodicals in Social Work are always ordered by the library management.

\section{References}

Carpenter, R.L. and Vasu, E.S. (1978). Statistical Methods for Librarians. American Library Assocition. Chicago. P $1-3$.

Downie, J Stephen (1996). Information and the World Wide Web: A case study and discussion. In proceedings of Canadian Association for Information Science held in University of Toronto, Ontario, edited by Charles Meadow et al. Canadian Association for Information Science. P 130 $-141$.

Elllis, D. Cox, and Hall, K. (1993). Comparison of information seeking patterns of researchers in physical and social sciences. Journal of Documentation 49, No. 4: 356 369.

EMC Corporation (2007). The expanding digital universe: a forcast of worldwide information growth through 2010. Retrieved May 9, 2007 from http://www.emc.com/about/destination/digi tal universe/

Folorunso, O. (2004). HIV/AIDS Information Needs and Source: A Study of Secondary School Students in Osun State, Nigeria.
Gateway Library Journal Vol 7 (2), 42 48.

Hans - Christoph Hobohm, (1999b) Social Science Information and Documentation Time for a state of the art? Paper presented at the $65^{\text {th }}$ IFLA Council Conference, Bangkok, August 20 - 28, 1999.

Hobohm, Hans - Christoph (1999a) Social Science Information and Documentation In: World Social Science Report Paris. UNESCO, 172 - 181.

HOD, SWK, UNN (2007). Oral interview report. Nworgu, B.G. (2006). Educational Research. Basic Issues and Methodology. $2^{\text {nd }}$ edition. University Trust Publishers, Nsukka.

Pincus, A. and Anne, M. (1973). Social Work Practice Model. Itasca, III: F.E. Peacock Publishers. $68-70$.

Savolaninen, R. (1999). The role of the Internet in information seeking. Putting the network services in context. Information processing and management. 35 (6), $765-782$.

Wales, T. (2000). Practice makes perfect? Vets information seeking behavioural and information use explored. Aslib proceedings, 52 (7), $235-246$. 